\title{
«En helt anden måde at skrive på» Et studie i skriftlighed i projektarbejde med tysk som fremmedsprog
}

\author{
av Karen Sonne Jakobsen
}

Artiklen prosenterer et studie i skriftlighed i et tvarfagligt projektarbejde $i$ et dansk gymnasium med fagene tysk og historie. Fokus er på hvordan eleverne arbejder med skriftlighed: Hvad bruger eleverne skriftlighed til i projektarbejdet? Hvilke aspekter af sprog, tekst og skriveproces arbejder de med? Hvilken betydning tillagger de skrivning på fremmedsproget $i$ deres laering og selvopfattelse som brugere af et fremmedsprog? Studiet bygger på sociokulturel teori med henblik på literacy og identitetsaspekter af sprogloering. Det omfatter analyser af elevers samarbejde om at skrive et tysksproget abstract og af interviews med elever om deres identifikationer med at bruge tysk til faglige formål. Til slut diskuteres hvordan projektarbejde med fremmedsprog kan bidrage til at udvikle elevers studieforberedende skrivekompetencer.

Studiet er et delprojekt under forskningsprojektet Faglighed og Skriftlighed, finansieret af det danske forskningsråd for humaniora, FKK (2011-2014). Projektet er et samarbejde mellem forskere ved Syddansk Universitet, Aarhus Universitet og Roskilde Universitet www.sdu.dk/fos

\section{Fremmedsprog i projektarbejde. Udfordringer og forskningsbehov}

Ved en reform af den danske gymnasieskole i 2005 er tværfagligt projektarbejde gjort obligatorisk i alle tre gymnasieår. Formålet er almendannende og studieforberedende, dvs. projektarbejdet skal fremme elevernes kreative og innovative evner og kritiske sans, lære dem at anvende faglig viden i fagligt samarbejde og at forholde sig reflekterende og ansvarligt til deres omverden og deres egen udvikling. Gennem de seneste år er der kommet særligt fokus på skriveopgaver der er knyttet til de tværfaglige projekter, og som skal bidrage til at eleverne udvikler studieforberedende skrivekompetencer (Krogh 2010). 
Fra reformens begyndelse er det tværfaglige projektarbejde blevet opfattet som en udfordring for fremmedsprogene til at udvikle indhold og arbejdsformer i samarbejde med andre fag. Projektarbejdet giver mulighed for at elever oplever deres fremmedsprog i brug og lærer at anvende det til faglige formål. Med det stærke fokus der er kommet på sproglige kompetencer og specielt på skriftlighed, kan sprogfagene træde ind $i$ en ny rolle som formidler af sproglig viden og kunnen som ikke kun har relevans for det enkelte sprog, men også for udvikling af skrivekompetencer generelt.

I den fremmedsprogspædagogiske forskning findes der ikke megen empirisk baseret forskning om projektarbejde i fremmedsprogene som reformen kunne støtte sig på (jf. Beckett \& Miller 2006, Vollmer 2007). I en oversigt over forskning der er relevant for projektbaseret læring af fremmedsprog, noterer Stoller med basis i den amerikanske kontekst at efter mere end 20 års praksis støtter undervisningen sig endnu primært på "anecdotal reports”, og hun efterlyser empirisk forskning i projektarbejdets forskellige aspekter (Stoller 2006:34f.). For den europæiske situation vurderer Vollmer at med den vægt der ligger på en kompetencebaseret tilgang til undervisning og læring af fremmedsprog, er projektarbejde blevet en pædagogisk betydningsfuld arbejdsform; han efterlyser ligeledes mere forskning, især på området "subject- and topic-specific forms of text processing" (Vollmer 2007:55).

I kølvandet på den danske gymnasiereform er der begyndt at komme forskning med fokus på tværfagligheden, hvordan den opfattes og praktiseres (Harnow Klausen 2011, Zeuner 2012). Skriftlighedens rolle i tværfagligt projektarbejde er blevet undersøgt af Christensen (2009) og Hobel $(2009,2011)$. På baggrund af studier i gymnasieelevers skriftlige opgaver foreslår Hobel et begrebsapparat som lærere og elever kan anvende i forbindelse med vejledning og feedback på tværs af fag (Hobel 2011:142). Det studie jeg præsenterer i det følgende, ligger i forlængelse af Christensen og Hobel ved at fokusere på skriftlighed og på de tekster eleverne producerer som led $\mathrm{i}$ projektarbejdet, men med brugen af fremmedsproget og med elevernes oplevelse af den fremmedsprogede skriftbrug i centrum (jf. også Jakobsen 2005).

\section{Et sociokulturelt syn på literacy / tekstkompetence. Teoretisk baggrund og forskningsspørgsmål}

I forskningsprojektet Faglighed og Skriftlighed har vi udviklet en model for hvordan vi forstår forskningsfeltet som de enkelte delprojekter bygger på (se Fig. 1). Med basis i sociokulturel teori og inspireret af især New Literacy Studies (Barton 2007, Street 1995) betragter vi skriftlighed som social praksis med skrifthændelsen som omdrejningspunkt, dvs. "any activity which involves the written word" (Barton 2007:37). I projektet fokuserer vi på skrivehcendelser, dvs. elevers skrivning som formes af skoleinstitutionen, af fagene og af eleverne og deres liv uden for skolen, herunder deres skrivepraksis. Trekantens tre ben symboliserer at vi i skolen finder skriftpraktikker som er udtryk for forskellige skriftkulturer. Hvis vi tager tværfagligt projektarbejde som eksempel, findes der i den lokale skoleskriftkultur traditioner og normer for hvordan skrivning i projektarbejder gribes an og styres. De tilknyttede lærere som har baggrund i hver deres faglige skriftkultur, har til opgave at formidle en faglig og fagovergribende skriftkultur, f. eks. at kunne skrive en 
problemformulering. Eleverne praktiserer en elevskriftkultur hvor de i deres skrivning også kan trække på deres skrivepraksis uden for skolen, f. eks. i deres brug af digitale ressourcer eller deres måde at organisere samarbejde på om skrivning. (For en uddybende forklaring af modellen se Krogh \& Hobel 2012.)

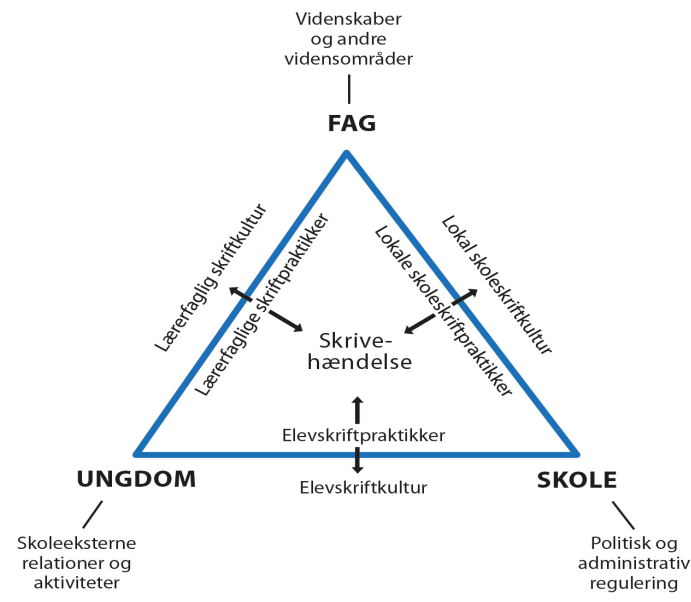

Figur 1. Model til analyse af skrivehændelser i skolen

Dette delprojekt er et studie i elevers skrivepraksis i tysk med henblik på at undersøge lceringsmuligheder (Lantolf 2000:17) i anvendelsen af andet fremmedsprog inden for rammerne af tværfagligt projektarbejde. Det er et eksplorativt studie som gennem en kvalitativ analyse af skriftlighed i et projektforløb vil give et bud på følgende spørgsmål:

Hvad bruger elever skriftlighed til i projektarbejdet?

Hvilke aspekter af sprog, tekst og skriveproces arbejder de med?

Hvilken betydning tillægger de skrivning på fremmedsproget i deres læring og deres selvopfattelse som brugere af et fremmedsprog?

De to første spørgsmål retter sig mod brugen af skriftlighed som fagligt redskab og som basis for læring og bevidsthedsdannelse om sprog og tekstproduktion. I dette studie vil jeg fokusere på et skriftligt produkt - et tysksproget abstract - og på skriveprocessen i en projektgruppe. Med basis $\mathrm{i}$ et sociokulturelt sprog- og læringssyn (Swain 2000, Donato 1994) vil jeg analysere elevernes kollaborative skrivning af teksten og de aspekter af sprog, tekst og læring de arbejder med og tematiserer. Med støtte i Claire Kramsch' arbejder om den subjektive betydning af at lære og bruge fremmedsprog (Kramsch 2009) vil jeg inddrage elevernes identifikationer med sprogbrugen og den betydning de tillægger skrivning på et fremmedsprog. Tilsammen skal spørgsmålene belyse forskellige, men sammenhængende aspekter af skriftlighed i projektarbejdet: skriftbrug som fagligt redskab og som sproglig bevidstheds- og identitetsdannelse. 
Studiet er et bidrag til den sprogpædagogiske forskning som gennem de senere år har inddraget indsigter fra New Literacy Studies i sit teoretiske og metodiske grundlag. Det indebærer at læsning og skrivning ikke opfattes som adskilte sproglige færdigheder, men som en sammenhængende sproglig, kognitiv og social praksis. Hvad det vil sige at blive literate $\mathrm{i}$ et fremmedsprog, formulerer Richard Kern således:

Becoming literate is therefore not so much a matter of achieving a particular criterial level of reading or writing performance, as it is a matter of engaging in the everdeveloping process of using reading and writing as tools for thinking and learning, in order to expand one's understanding of oneself and the world (Kern 2000:39f).

Inden for forskningen i tysk som fremmed- og andetsprog har Portmann-Tselikas udarbejdet et begreb om tekstkompetence der ligeledes lægger vægt på at færdigheder udgør et integreret hele:

...at kunne læse tekster selvstændigt, at kunne relatere det læste til ens egne kundskaber og at kunne bruge den således vundne information og viden til videre tænkning, tale og handling. At kunne fremstille tekster for andre og derigennem meddele tanker, holdninger og hensigter på en forståelig og adækvat måde (PortmannTselikas 2005:1, min oversættelse).

Også Portmann-Tselikas trækker på literacy-forskningen, men med en stærkere betoning af literacy som kompetence. En vigtig pointe hos ham er at 'åbne' undervisningsformer - som bl. a. projektarbejde - på grund af deres kompleksitet forudsætter tekstkompetence som det derfor er sprogfagenes opgave at formidle (Portmann-Tselikas 2002:23). I forhold til denne tese er mit studie et bidrag til at undersøge hvorvidt projektarbejdet - netop i kraft af sin kompleksitet - kan udgøre en social kontekst hvor elever engagerer sig $\mathrm{i}$ brug af læsning og skrivning af fremmedsprogede tekster og derigennem får mulighed for at udvikle tekstkompetence.

\section{Et projekt om Globalisering / grcenser. Kontekst, data, metode}

Studiet er gennemført som et feltarbejde hvor jeg over fire dage har fulgt en gymnasieklasse under deres projektforløb, et såkaldt AT-forløb (Almen studieforberedelse). Det er en 2. G med 17-18årige elever som har haft tysk tre år i grundskolen og er i gang med deres 2. år i på gymnasieniveau. Det er deres femte tværfaglige projektforløb, så de er ganske rutinerede. I dette forløb indgår fagene tysk og historie med særligt fokus på metoder, materialer og teori. Temaet for forløbet er Globalisering/graenser. Der er to vejledere tilknyttet, én fra hvert af fagene. Kravene til elevprodukterne er en synopsis med et tysksproget abstract (jf. 4.1), en gruppefremlæggelse hvoraf en del er på tysk, og et talepapir med stikord. Endvidere skal grupperne fungere som opponent for hinanden ved fremlæggelserne. 
Der blev dannet 6 grupper med 3-5 elever som har udarbejdet hver deres problemformulering inden for temaets rammer. Særligt for dette projektforløb er at klassen fik besøg af gymnasieelever fra den dansk-tyske grænseregion som de interviewede som led i projektet. Før projektforløbet gik i gang, havde klassen i tysktimerne læst tysksprogede tekster i en lærebog der er udgivet med henblik på tværfagligt samarbejde, Grcenseland - krig og kulturmøde (Hermann m. fl. 2009).

Mit datamateriale består af en feltrapport over de fire dage, gruppernes synopser, gruppeinterviews og et lærerinterview. Jeg observerede forløbet fra start til og med de afsluttende fremlæggelser. I løbet af de fire dage kom jeg rundt i de fleste grupper og kunne observere hvordan de håndterede forskellige faser af arbejdet. Mit hjælpemiddel var min lap top hvor jeg tog udførlige noter fra interaktionerne i grupperne. Efter afslutningen gennemførte jeg interviews med grupperne (optaget på lydfil) hvor jeg spurgte til deres oplevelse af projektarbejdet og specifikt til deres arbejde med tysk og med abstractet. Gennem lærerinterviewet fik jeg indblik i pædagogiske intentioner og vejledningsopgaver i tværfaglige projektforløb.

Metodisk bygger studiet på en kombination af en etnografisk og tekstanalytisk tilgang. På basis af observationer analyseres først projektforløbet som en helhed bestående af forskellige typer af skrivehændelser og -processer. Dernæst koncentreres analysen om abstractet og om skriveprocessen $i$ en enkelt gruppe for at vise hvilke ressourcer den trækker på og hvordan den samarbejder om tekstproduktionen. Endelig inddrages gruppeinterviews for at belyse den subjektive betydning eleverne tillægger deres skrivepraksis og arbejde med skriftlig tysk i projektet. Derudover inddrages elev- og lærerinterview løbende $\mathrm{i}$ fortolkningen af skrivehændelser og -proces.

\section{En kompleks skriftpraksis. Analyser og resultater}

Projektforløbet er en proces hvor der skrives meget. Vi skrev hele tiden. Det er ikke engang løgn, som en af eleverne siger i et interview. Men der skrives ikke bare meget, der er tale om hvad jeg vil kalde en kompleks skriftpraksis som involverer forskellige typer af processer. Nedenfor er oplistet en række af forskellige typer af skrifthændelser som indgår i projektforløbet, og som på forskellig vis involverer skriftlighed. Rækkefølgen skal ikke tages bogstaveligt som en faseopdeling; der er overlapninger, f. eks. mellem interviews og problemformulering (se Tabel 1).

\section{Tabel 1}

$\begin{array}{llll}\text { Skrifthændelser i projektforløbet } & \text { Sprog } & \text { Modalitet } \\ \text { 1. Læsning af tekster } & \text { tysk } & \text { skrift } \\ \text { 2. Historiefaglige oplæg } & \text { dansk } & \text { tale } \\ \text { 3. Oplæg v. unge fra mindretallene } & \text { dansk-tysk } & \text { tale } \\ \text { 4. Interviews } & \text { dansk-tysk } & \text { tale }\end{array}$




$\begin{array}{lll}\text { 5. Problemformulering } & \text { dansk } & \text { skrift } \\ \text { 6. Besvarelse af delspørgsmål } & \text { dansk } & \text { skrift } \\ \text { 7. Redigering af synopsis } & \text { dansk } & \text { skrift } \\ \text { 8. Skrivning af abstract } & \text { tysk } & \text { skrift } \\ \text { 9. Skrivning af talepapir } & \text { tysk } & \text { skrift } \\ \text { 10. Fremlæggelse } & \text { dansk-tysk } & \text { tale }\end{array}$

Med Kerns begreber (2000) kan skrifthændelserne karakteriseres som processer hvor eleverne analyserer, fortolker og transformerer diskurs, hvor de skaber og transformerer viden og hvor de udvikler metakommunikativ bevidsthed (Kern 2000: 303f.). Eleverne læser, analyserer og fortolker tysksproget tekst - f. eks. indgår der i flere af gruppernes arbejde et tysksproget digt - som i synopsen transformeres til dansksproget diskurs om mindretal og identitet. Ved skrivning af abstract og talepapir transformeres identitetsdiskursen til tysksproget metadiskurs om gruppens arbejde med identitetsspørgsmål (jf. ndf. 4.1).

Samtidig er der tale om skift mellem forskellige modaliteter (Kress 2003) og transformationer af modaliteter - f. eks. fra mundtlige interviews til tekstafsnit i synopsen - og forskellige kombinationer af sprog, dansk og tysk. (Tabellens opdeling i tale og skrift er ikke ganske retvisende; i realiteten er tale og skrift tæt sammenvævet i de fleste aktiviteter.) Oplæg og interviews er markeret med begge sprog idet de tosprogede interviewpersoner taler et regionalt farvet dansk, og nogle af eleverne vælger at gennemføre interviews på tysk. Der er altså tale om en flersproget skriftlighed som omfatter læsning og skrivning på (mindst) to sprog og kombinationer af (mindst) to modaliteter. ${ }^{1}$

I nogle faser af processen har jeg observeret et tæt samarbejde om skrivning i grupperne: problemformulering, redigering og skrivning af abstract (markeret med kursiv i Tabel 1). I problemformuleringsfasen er det afgørende for gruppen at opnå en fælles forståelse af problemstillingen og her spiller kollaborativ skrivning (Donato 1994) en central rolle. Det er også den fase som både af elever og lærer opleves som den på én gang vigtigste og vanskeligste. Arbejde med delspørgsmål foregår i nogen grad arbejdsdelt. I redigeringsfasen er der igen - eller kan der være - et tæt samarbejde i gruppen. Det er opgaver som er højkomplekse; om gruppen opnår et godt resultat $\mathrm{i}$ form af en præcis og kohærent synopsis, er afhængig af hvordan de bruger denne fase. I interviews giver grupperne udtryk for at problemformuleringen og det at skabe "en rød tråd" er de vanskeligste opgaver i projektarbejdet.

\footnotetext{
${ }^{1}$ Andre sprog kan f. eks. være engelsk og minoritetssprog. Andre modi: billeder og videoer i forberedelsesfasen, power point-show ved fremlæggelsen.
} 
Også skrivningen af abstractet foregår kollaborativt. Det er en svær opgave som kræver at gruppen puljer deres ressourcer for at løse den; der er tale om en kompleks transformation fra én genre, synopsen, til en anden, abstractet, fra ét sprog til et andet, fra faglig diskurs til metadiskurs. Jeg vil i det følgende se nærmere på abstractet og hvordan eleverne arbejder med denne opgave.

\subsection{Tysksprogede abstracts. En ny genre}

Som led i projektarbejdet skal eleverne i grupper skrive en dansksproget synopsis og et tysksproget abstract. En synopsis er et skriftligt produkt på tre til fem sider hvor eleverne skal

- udarbejde en titel og angive hvordan de vil inddrage de 2 fag for at besvare problemformuleringen

- udarbejde en problemformulering og med særlig fokus på teori og metode arbejde med de væsentligste problemstillinger

- præcisere de væsentligste konklusioner

- udarbejde en korrekt litteraturliste

(Citeret fra skolens beskrivelse af krav til projektet)

I dette forløb er abstractet ikke obligatorisk, men en mulighed som holdet har valgt at bruge. Der findes således ingen formelle krav til abstractet, men for andre projektforløb i gymnasiet findes der vejledning for udformning af et resumé (abstract og resumé bruges synonymt). Et resumé fylder 10-20 linjer og skal

- i koncentreret og sammenhængende form præsentere opgavebesvarelsens vigtigste elementer

- i sig selv udgøre en meningsfuld helhed og kunne forstås uafhængigt af opgavebesvarelsen

- indeholde en præsentation af undersøgelsens problemstilling, de væsentligste resultater og konklusioner

(Stx Vejledning / Råd og vink Oktober 2010)

Mens eleverne synes ganske fortrolige med synopsis-genren - som nævnt er det femte gang de skriver en synopsis - giver de udtryk for usikkerhed over for abstractet. I interviews siger to af eleverne at de har lært hvordan man skriver et abstract $i$ fysik, men de ved ikke hvordan de skal gribe det an i et humanistisk fag. Det er sandsynligvis derfor der er en vis bredde i elevernes formulering af abstractet som tekst; de er ikke kalkeret over et standardiseret skema, men er udtryk for elevernes egne opfattelser af hvad et abstract skal være og hvordan det skal formuleres. ${ }^{2}$

\footnotetext{
2 De følgende citater er nøjagtige gengivelser af gruppernes abstracts som ikke er korrigeret. Ved projektevalueringen gives der ingen særskilt bedømmelse for sproglig form. Projektet evalueres som en helhed hvor der bl. a. lægges vægt på om gruppen kan begrunde de valg den har truffet, og de metoder og begreber den har arbejdet med. Gruppe X hvis skriveproces i det følgende vil blive analyseret nærmere, blev bedømt til at ligge på et godt middelniveau.
} 
Den type skrivehandling 3 eleverne vælger i deres abstracts, er den ekspositoriske (Togeby, under udgivelse), som grupperne udfører på forskellige måder: Nogle er rapporterende idet gruppen beretter om deres arbejde i fortid (Eks. 1), nogle er objektcentrerede og holdt nutid (Eks. 2), nogle en mellemting (Eks. 3).

Wir haben über die dänische und deutsche Minderheit geschrieben. Wir haben auf die Identität der Minderheit fokussiert (...) Hierdurch konnten wir feststellen, dass...

[Vi har skrevet om det danske og tyske mindretal. Vi har fokuseret på mindretallets identitet... Herigennem kunne vi konstatere, at...]

\section{Eksempel 1}

Die folgende Aufgabe enthält eine Antwort auf das oben genannte Problem Formulierung (...) Es gibt viele Faktoren die beeinflussen, wie die Minderheit heute sieht aus.

[Den følgende opgave indeholder et svar på den ovenfor omtalte problemformulering (...) Der findes mange faktorer der har indflydelse på hvordan mindretallet ser ud i dag.]

\section{Eksempel 2}

Unser Hauptthema in dieser AT-Verlauf war Grenzland und Identität (..) Wir haben eine übergeordnete Frage und fünf erklärende Frage (...) Unsere Schlussfolgerung war...

[Vores hovedtema i dette AT-forløb var grænseland og identitet. Vi har et overordnet spørgsmål og fem forklarende spørgsmål (..) Vores konklusion var...]

\section{Eksempel 3}

Uanset den valgte stil repræsenterer abstractene samme skrivehandling: på kort plads og på en objektiv måde at informere læseren om gruppens arbejde. Grupperne gør brug af skriftsproglige ressourcer til at producere en informationstæt og kompleks tekst som samtidig er en bearbejdelse af og refleksion over deres projektarbejde (jf. Maas 2010:44f). Det en kompliceret operation som ikke alene består $\mathrm{i}$ at sammenfatte indholdet, men også at bevæge sig op på et diskursivt metaniveau. Hertil anvender grupperne hvad jeg vil kalde metadiskursive verber: schreiben, fokussieren, feststellen [skrive, fokusere, konstatere] eller nominaliseringer af sådanne verber: Frage, Schlussfolgerung [spørgsmål, konklusion], også med udvidelser: übergeordnete Frage, erklärende Frage [overordnet spørgsmål, forklarende - sandsynligvis menes uddybende - spørgsmål].

\footnotetext{
${ }^{3}$ Begrebet skrivehandling stammer fra det norske Skrivehjulet http://lesesenteret.uis.no/leseopplaering/ skjulte dokumenter/article2114-975.html Betegnelsen for den enkelte type af skrivehandling stammer fra Togeby (under udgivelse).
} 
Abstractets globale, tematiske kohærens skabes af kompositionen som følger mønstret i de overordnede skridt $\mathrm{i}$ et projektforløb (se gruppe X's abstract i fuld ordlyd i i appendiks). Først introduceres emnet: In unsere Aufgabe, haben wir über die dänische Minderheit in Deutschland und der deutschen Minderheit in Dänemark geschrieben [I vores opgave har vi skrevet om det danske mindretal $i$ Tyskland og det tyske mindretal $i$ Danmark], dernæst problemformuleringen med underspørgsmål: Unsere Fragestellung heißt ...[Vores problemformulering er...] og endelig resultaterne: Unsere Untersuchung Zeiger...[Vores undersøgelse viser...]. Med begreberne Aufgabe, Fragestellung, Untersuchung [opgave, problemformulering, undersøgelse] fastholdes fokus på metaniveau i forhold til det arbejde der præsenteres.

Det sproglige register (Halliday 1978) er præget af et fagligt, begrebsligt ordforråd som Identität, Doppelidentität, Identitätsbildung [identitet, dobbeltidentitet, identitetsdannelse], herunder ord som tilhører både et alment og et fagligt register som Kultur, Nationalgefühl, Persönlichkeit [kultur, nationalfølelse, personlighed]. Hertil hører udtryk som:

eine Wirkung haben [have virkning på]

Einfluss haben / beeinflussen [have indflydelse på / påvirke]

Bedeutung haben [have betydning]

Eksempel 4

Ordforbindelserne tilhører det hverdagslige videnskabssprog (Ehlich 1999) som bruges både i og uden for faglige diskurser, og som er forudsætning for at kunne udtrykke sig og handle fagligt på tværs af fag.

I deres abstracts arbejder eleverne med skriftsprogstræk der er centrale for denne faglige teksttype. De opfatter abstractet som en særlig genre der skal tjene et bestemt formål, og de har givet det en opbygning og valgt begreber og ordforbindelser der understøtter dette. Da elevernes erfaring med skrivning af abstracts på dette tidspunkt endnu er begrænset, må de bringe forskellige typer af viden i spil for at løse opgaven, herunder sproglig viden og viden om transfermuligheder fra dansk. Som de ganske erfarne projektskrivere de er, har de en viden om de vigtigste stationer i arbejdsprocessen som de bruger som et skema for teksten (jf. Togeby, under udgivelse). I interviewet med læreren peger hun på at klassen har arbejdet meget med genrer, og derfor har en generel genrebevidsthed der kommer dem til gode. Sandsynligheden taler for at gruppen kombinerer flere videnskilder for på fremmedsproget at konstruere en for dem endnu ny teksttype. 


\subsection{Processen. Kollaborativ skrivning af et abstract}

Et af de abstracts der blev analyseret ovenfor, er skrevet af gruppe X - Anna, Frida, Mie, Sofie og Søren - i skiftende konstellationer med kortvarig inddragelse af læreren. Arbejdsformen i gruppen kan beskrives som flydende idet nogle af gruppens medlemmer udgør en kerne der arbejder kontinuerligt, mens andre går til og fra. Læreren inddrages ad hoc.

Følgende observation (Eks.5) stammer fra skrivningen af abstractets første afsnit: ${ }^{4}$

Anna: Ok læs lige herfra. Wir haben..

Søren: Det kommer an på hvad køn Bildung er.

[Tager sin pc frem.]

Søren: Det er hunkøn.

Anna: Og hvilken indflydelse..

Søren: Einfluss

[Slår op i elektronisk ordbog]

Anna: Fühle.. jeg har det lige på tungen..

Søren: Gefühl

[Feltrapport]

Eksempel 5

Anna indleder sekvensen med en opfordring til Søren om at hjælpe med formuleringen på tysk og Søren giver hjælpen med dels en grammatisk kommentar om køn, dels ved at levere gloser. Den elektroniske ordbog er en vigtig ressource. Den næste observation (Eks. 6) stammer fra skrivning af problemformuleringen:

Anna: Skal det ikke være die, der er to..

Søren: Det er flertal..

[Intenst samarbejde mellem Anna og Frida ved skærmen, assisteret af Søren]

Anna: Hvorfor..

Søren: Warum..

Anna: Ja det lyder bedre. Bedeutung det er også med stort.

Anna: Yes mand hold kæft hvor er det godt.. Kan vi lige trykke den over til tysk.

[Gruppen arbejder ind over pausen]

[Feltrapport]

Eksempel 6

Her samarbejder Anna og Søren assisteret af Frida som fungerer som skriver. Eksemplerne viser at gruppen trækker på og deler grammatisk og leksikalsk viden, viden om ortografi og sproglig intuition: Ja det lyder bedre. De har indtil nu ikke brugt tysk stavekontrol, men slår den til nu. De

\footnotetext{
${ }^{4}$ Gruppesamtalerne er ikke optaget på lydfiler, men bygger på tætte noter fra feltarbejdet. Samtalerne er gengivet så nøjagtigt som muligt under de givne betingelser. De skal bidrage til et helhedsbillede som også baseres på øvrige observationer.
} 
er inde $\mathrm{i}$ et flow, arbejder koncentreret og $\mathrm{i}$ højt tempo ind over spisepausen. Den følgende observation (Eks. 7) er fra skrivningen af det sidste afsnit:

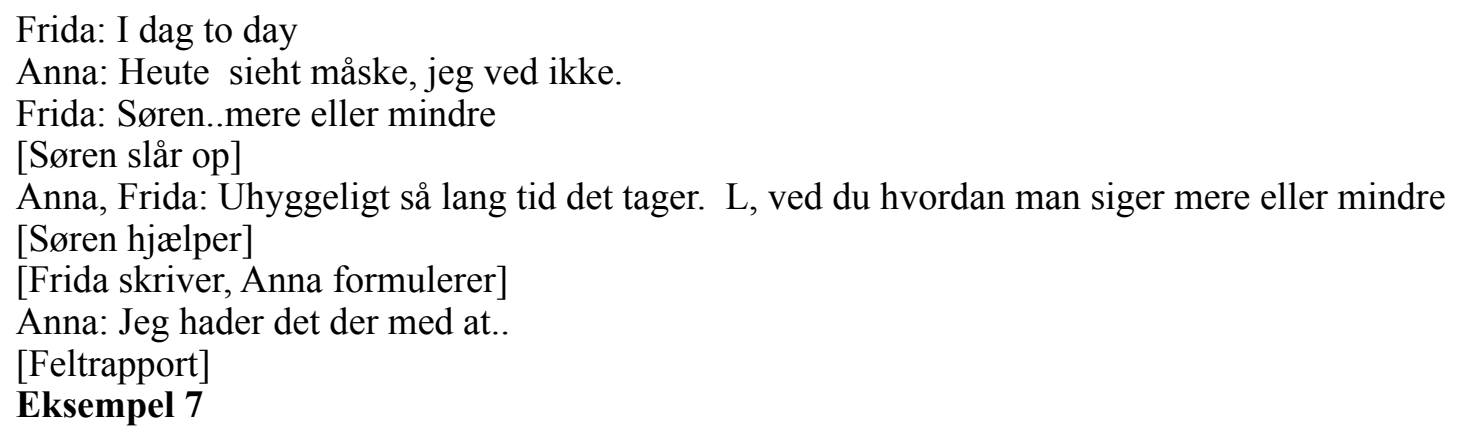

Arbejdsdelingen er at Anna formulerer, Frida skriver, men tager ind imellem også initiativer, Søren bidrager med ord. Anna nedtoner sin sproglige kompetence ift. de andre og beder om hjælp til gloser (Eks. 7 og 8).

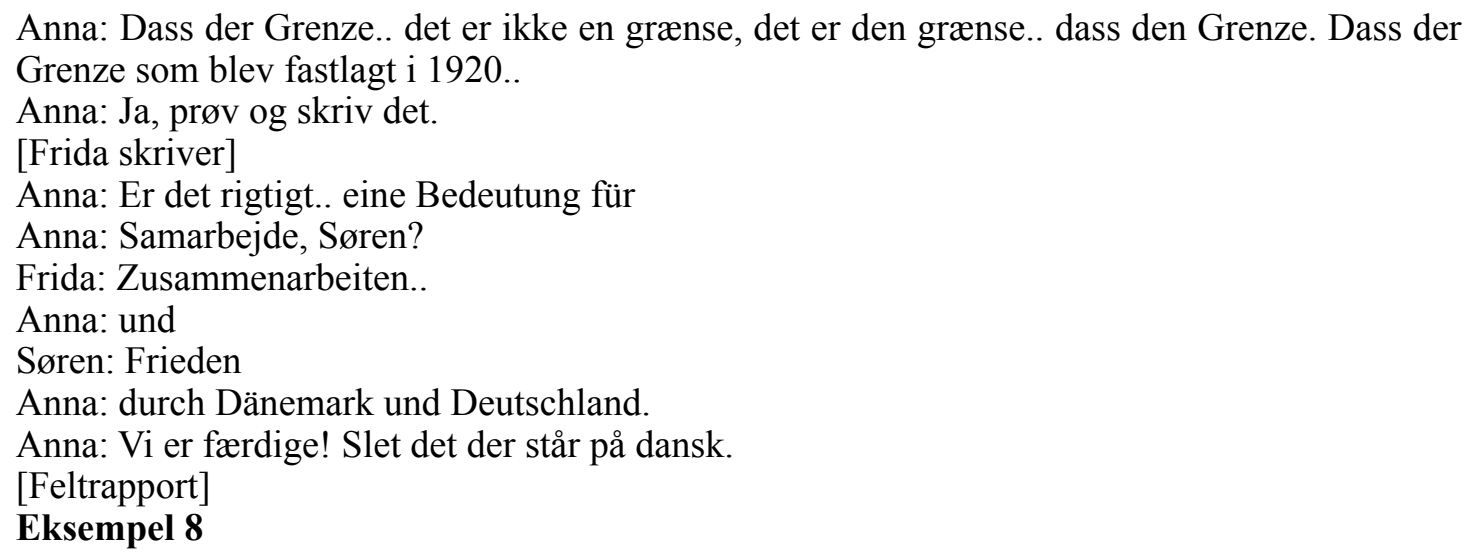

Observationerne viser et tæt samarbejde om skrivning hvor eleverne tager forskellige roller og trækker på hinandens ressourcer. I den sidste afsluttende del (Eks. 8) er samarbejdet mellem Frida, Anna og Søren så tæt at de formulerer abstractets sidste sætning uden overgange fra den ene taler til den anden. Processen er et eksempel på kollektiv scaffolding, hvor eleverne ko-konstruerer den hjælp de har brug for, for at kunne producere teksten (Donato 1994). Med henvisning til Wood, Bruner og Ross (1976) nævner Donato seks træk der karakteriserer scaffolding:

1) recruiting interest in the task

2) simplifying the task

3) maintaining pursuit of the goal

4) marking critical features and discrepancies between what has been produced and the ideal solution 
5) controlling frustration during problem solving

6) demonstrating an idealized version of the act to be performed

(Donato 1994:41)

Næsten alle disse træk findes hos gruppen, ikke kun de sproglige, men i høj grad også de sociale med det resultat at gruppen bevarer koncentrationen og "kontrollerer frustration" gennem hele forløbet. Midt i forløbet forsøger gruppen at inddrage læreren med en appel om at levere en "idealiseret version" af et udtryk (mere eller mindre), dvs. en version der accepteres af gruppen som en model for det sproglige problem der skal løses (Donato1994:47). Men læreren er ikke lige til at få fat $\mathrm{i}$, så gruppen må selv konstruere en version der kommer så tæt som muligt på den "idealiserede" (mehr oder weniger, jf. abstractet).

I forhold til punkt 2) - simplifying the task - spiller læreren derimod en central rolle. Da gruppen går i gang med at skrive abstractet, begynder de med at oversætte fra en tekst de har skrevet på dansk, men de løber hurtigt ind i oversættelsesvanskeligheder og tilkalder læreren. Hun råder dem til at forenkle det de vil sige så de kan sige det på tysk, dvs. snarere end at bidrage til at løse problemet direkte anbefaler hun en skrivestrategi som gør at gruppen selv kan arbejde videre med opgaven (jf. ndf. 4.3). Både lærer og elever bidrager således til den kollektive scaffolding, men på forskellig vis.

Frida og Anna, der begge har været meget aktive i skrivningen, gør sig tanker om processen, også om de læreprocesser der er involveret. I interviewet med gruppe X beskriver Anna samarbejdet således:

[...] man sidder og snakker sammen, og så hvis der er noget vi er i tvivl om, så spurgte vi lige de andre, og så kunne de måske også lige sige nogle ord vi ikke lige kunne huske og sådan noget eller kunne finde ud af. [Interview gruppe $\mathrm{X}$ ]

Eksempel 9

Frida tematiserer det arbejde der skal præsteres for at finde den rigtige formulering og det læringsudbytte det giver:

Jeg har det også sådan at man tænker lidt mere over tingene når man selv skal sidde øh rigtig koncentreret. Og så okay: Nu skal man altså lave det her og finde ud af hvad der er det rigtige. Så koncentrerer man sig også meget mere om det, og så får man også mere ud af det end hvis det bare er sådan noget: Så ind på google translate, så er det oversat. Det får man jo ikke noget ud af, vel? [Interview gruppe X]

Eksempel 10

Det er karakteristisk for Anna at hun både i interaktionerne i gruppen og i interviewet (Eks. 9) nedtoner sin rolle som gruppens ekspert og den der, hjulpet af Søren, giver flest bud på idealiserede 
versioner. Hermed støtter hun samarbejdet og gruppens fælles resultat. Frida er som nævnt også aktiv, men i en mindre initiativtagende rolle, og det er derfor interessant at hun så tydeligt giver udtryk for at den giver hende et godt læringsudbytte (Eks. 10). Den sociale dimension er væsentlig for at kollektiv scaffolding fungerer som læreproces.

Sammenholdt med analysen af abstractet er det påfaldende at samarbejdet i gruppen næsten udelukkende koncentrerer sig om ord, køn og stavning, altså sproglige træk på et lokalt niveau. Det afspejler muligvis det faktum at det er på dette niveau eleverne har de største problemer eller - og måske snarere - at de har lavet et udkast til abstractet på dansk, så de under skriveprocessen kan fokusere på den sproglige formulering. Denne opdeling af skriveprocessen er ikke uden videre ensbetydende med at eleverne oversætter den danske tekst til tysk; som det vil fremgå laver de snarere på basis af den danske tekst en parallel tysk version.

\subsection{Formulering på fremmedsproget. Transformation af viden}

Læreren anbefaler som nævnt gruppe $\mathrm{X}$ at forenkle teksten så de kan sige hvad de vil sige på tysk. Den strategi følger de:

Frida: Kommer vi ind på - snakker vi om, skriver vi om

[slår op i ordbog]

Skriver.

Frida, Mie:

[Kigger på skærmen og taler om formuleringer]

Schreiben til sidst.

[Fra feltrapport]

Eksempel 11

Umiddelbart er der tale om en sproglig omskrivningsproces - en reduktionsstrategi - hvor dansk omskrives til mere centrale, ikke-idiomatiske ordforbindelser som lettere kan udtrykkes på tysk: kommer vi ind på - snakker vi om - skriver vi om - skriver (Eks. 11). I interviewet kommer det frem at eleverne ikke ser denne proces som en ren sproglig proces, og at der heller ikke alene er tale om en reduktion af meddelelsen, men at der er mere involveret. I interviewet bliver de spurgt om det betyder noget at de skal skrive på basis af et projekt de selv har arbejdet med, sammenlignet med skriveopgaver på basis af en tekst:

Frida: Det gør det helt klart, for hvis man har læst noget og så skal formidle det, så er det svært at omformulere det. Men hvis man selv har det i hovedet og kan det stof man skal skrive ned, så er det nemmere at gøre det for eksempel sætningerne lettere på tysk end det vi havde skrevet på dansk. [Interview gruppe X]

Eksempel 12 
Anna: Ja, det er jo rigtig nok at når man så selv har det i hovedet, så har man også øh sådan bagtankerne om det hvordan man er kommet frem til det danske, og sådan kan man så også arbejde sig frem til det tyske. [Interview gruppe X]

Eksempel 13

Frida og Anna taler om den centrale proces i skrivning på et fremmedsprog, at formulere (jf. Portmann, 1991: 425). Portmann fremhæver at ved formulering på et fremmedsprog sker der en 'afautomatisering' af sprog og talemåder; en proces der kan iagttages ovenfor: På elevernes førstesprog melder der sig spontant idiomatiske udtryk som at komme ind på, mens de på tysk skal lede efter det bedst mulige udtryk som her er schreiben (Eks. 11).

At skrive et abstract på tysk indebærer at eleverne formulerer deres tanker på tysk på basis af den faglige viden og den viden om processen de har oparbejdet i projektet. Skrivning på tysk er en måde at bearbejde viden på parallelt med skrivning på dansk, mere krævende, men, som Anna siger, man kan arbejde sig frem til det tyske (Eks. 13). Også læreren er inde på at den centrale udfordring i projektarbejdet med tysk er at der skal et vidensniveau til og at det derfor gælder om at få lært eleverne nogle dybdestrategier (...) fordi hvis de kun bruger overfladestrategien med at huske, så får de jo ikke loert noget scerligt (Lærerinterview). Eleverne er enige i synspunktet samtidig med at de pointerer at den oparbejdede faglige viden giver basis for en mere selvstændig sproglig formuleringsproces, også på tysk.

\section{4 "En helt anden måde at skrive på". Skriftbrug og identitet}

Da gruppe X bliver spurgt om hvad de har oplevet som svært i projektarbejdet, svarer de at det er at skulle formulere sig på tysk, både $\mathrm{i}$ abstractet og ved den mundtlige fremlæggelse. Sprogbrugen $\mathrm{i}$ projektet er anderledes end den de kender fra tysktimerne, de skriver længere og under den mundtlige fremlæggelse taler de i længere tid. Men også det sproglige indhold og de sproglige funktioner er anderledes:

Frida: Ja, for man kan sige i tysk, der er det mere de basale ting man gennemgår, ikke? Sådan noget hvordan man siger, nu er det bare en lille ting, for eksempel hvordan man siger: Jeg hedder og sådan noget. Der er det mere sådan nogle basale ting, hvor det her, det er jo rent faktisk noget vi arbejder med, noget lidt mere kompliceret. Som handler om et stof som vi har læst os frem til. [Interview gruppe X]

Eksempel 14 
Eleverne har en høj grad af bevidsthed om deres tyske sprogbrug i projektarbejdet; når de bruger sproget til faglige formål, kræver det et mere komplekst sprog end det sprog der bruges til hverdagslig kommunikation (Eks. 14). Det er et gennemgående træk i gruppeinterviewene at eleverne føler at der bliver stillet andre sproglige krav og knyttet højere forventninger til sprogbrugen i forbindelse med projektet. Der skal være en højere grad af grammatisk korrekthed og det er i det hele taget "en helt anden måde at skrive på":

Hanna: Man skal både have gram / grammatikken i orden og bare helt det / skrivemåden og sådan noget. Det er bare en helt anden måde at skrive på synes jeg bare... så... Der skal man tænke rigtig meget. [Interview Gruppe Y]

\section{Eksempel 15}

Flere af eleverne har en klar fornemmelse af at de bevæger sig $\mathrm{i}$ et højere, mere formelt skriftsprogligt register som ikke kun er funktionelt til faglige formål, men også er ladet med sociale betydninger:

Ditte: [... ] det er sådan lidt altså mere formelt eller fint i sproget, når det er sådan mere tysk i skolen, så det mere man kan/ Det er lettere at sammensætte nogle sætninger, synes jeg, på en eller anden måde. Fordi man kan de der små hverdagsord. Ja, det ved jeg ikke. Det synes jeg bare ikke rigtig man kunne bruge i abstractet. For det var sådan lidt mere finere. [Interview Gruppe W]

Eksempel 16

Skriftligheden i projektarbejdet omfatter foruden synopsis og abstract også talepapir og mundtlig fremlæggelse som ligger $\mathrm{i}$ et andet, mere skriftsprogpræget register end det de er vant til $\mathrm{i}$ klasseværelset. Den forskel i retning af et formelt register Ditte oplever, er hun ikke udelt begejstret for:

Ditte: [...] personligt kan jeg faktisk bedre lide at man bare sidder nede i tysklokalet og det ikke skal være så fint. Og man kan tale sådan lidt frit fra leveren, og så mangler man måske lige et par ord eller et eller andet, så kan de komme sådan undervejs. [Interview Gruppe W] Eksempel 17

Ditte reagerer sensibelt på registerforskellene og det er åbenbart at der er identitet på spil i valg af sprogbrug, også på fremmedsproget (Eks. 16, 17). Brugen af tysk er ladet med subjektiv betydning, ingen elever giver i interviewene udtryk for et 'neutralt' forhold til sproget. Som Kramsch fremhæver, så er det at lære og bruge et fremmedsprog forbundet med "imagined identities, projected selves" (Kramsch 2009: 5), en dimension som hun tillægger væsentlig betydning i læringserfaringen. I forlængelse af Kramsch konstaterer Ben Rampton at læring af et fremmedeller andetsprog involverer social identitet:

So as someone's grasp of a different language develops, it is worth asking: which social categories, figures and stances do they (start to) explore through the non- 
referential, socially indexical possibilities of the language they're using, how, where, with whom and with what kinds of alignment? (Rampton 2011:1).

Det generelle billede i klassen er at eleverne identificerer sig positivt med sprogbrugen i projektet som udtryk for en faglig og mere selvstændig brug af fremmedsproget:

Mette: Jeg kunne godt lide at øh /at det nærmest kom op på et lidt højere niveau det faglige tysk, altså, de vi sagde på tysk, var lidt på et højere niveau, i stedet for at det altid er så tekstnært på den måde. Jeg kunne godt lide at man begyndte at analysere [Interview Gruppe $\varnothing]$

\section{Eksempel 18}

Peter: (...) man skulle formulere noget andet tysk end man er vant til, synes jeg. [...]normalt er det bare skoletysk, og så får man lidt hjælp, ikke? Men her skulle man ligesom stå på sine egne ben og prøve at formulere det, ikke? [Interview Gruppe Ø]

Eksempel 19

Eleverne er forskellige og de har i større eller mindre grad investeret identifikationer i undervisningen, men for en del af dem er der tydeligvis sociale identiteter på spil. Rollen som "tyskelev" kender de tilbage fra grundskolen, den er tryg og velkendt; foran dem ligger rollen som selvstændig, faglig kompetent bruger af et fremmedsprog som de afprøver gennem projektarbejdet (Eks 18). Den positive identifikation beror først og fremmest på at de bruger tysk til faglige formål som de selv har sat, og på den højere grad af selvstændighed i sprogbrugen. Som Peter siger: .. man skulle stå på sine egne ben og prøve at formulere det (Eks. 19).

\section{Læringsmuligheder og studieforberedende skrivekompetencer}

Nanna: AT-forløbet, det føltes mere naturligt. I hvert fald når vi skulle skrive det, og når vi skulle bruge det tyske sprog. [...] vi skulle selv sådan tage hånd over hvad vi gerne ville bruge tysk /det tyske sprog til, og det virkede bare mere naturligt. Og det, tror jeg, blev lidt mere virkelighedsrigtigt, lad mig sige det sådan. [Interview Gruppe Ø]

\section{Eksempel 20}

Hvilke læringsmuligheder ligger der i brug af skriftlighed i andet fremmedsprog i tværfagligt projektarbejde? Inden jeg forsøger at besvare dette spørgsmål, er der grund til at understrege at det studie jeg har præsenteret her, kun dækker et lille hjørne af de mangfoldige sproglige aktiviteter et tværfagligt projektarbejde fører med sig. På basis af de aspekter jeg har analyseret, mener jeg dog at man pege på følgende træk som ikke alene vedrører skriftligheden i tysk, men har et bredere potentiale til at udvikle elevernes studieforberedende skrivekompetencer.

Det første jeg vil pege på, har netop med mangfoldigheden og kompleksiteten at gøre. Skrivekompetence handler ikke alene om at kunne skrive tekster i bestemte genrer på bestemte måder, men om at kunne omgås en mangfoldighed af tekster der indgår i et projekt eller en studieopgave på komplekse måder. Fremmedsproget bidrager til kompleksiteten idet eleverne bevæger sig i og mellem to sprog i deres videnstilegnelse og -formulering. Skrivekompetence kan 
ikke ses isoleret, men er et element $\mathrm{i}$ en bredere tekstkompetence/ literacy hvor evnen til at reformulere viden og transformere tekster til nye formål er central (Kern, 2000:208f., SchmölzerEibinger 2008:200f.)

Det andet vigtige punkt er at projektarbejdet udgør en rig kontekst for forskellige typer af skriveopgaver som har et tydeligt formål, samtidig med at de er så åbne at der er god plads for eleverne til at udforme og arbejde med teksterne. Det er abstractet et eksempel på. At abstractet skrives på et fremmedsprog, betyder at formen ikke indfinder sig af sig selv; der skal arbejdes bevidst med formuleringen. At den ikke i alle henseender svarer til etablerede standarder, er i denne forbindelse sekundært. Væsentligt er det derimod at eleverne selv afprøver at skabe sammenhoeng mellem tekstens funktion og form. Hvis kontekst og formål er tilstrækkeligt veldefinerede og eleverne har ressourcer at trække på, er det en opgave der udfordrer elevernes sproglige kreativitet og kunnen. Samarbejdet i gruppen er den afgørende ressource for at opgaven kan løses med udbytte, ikke kun i teknisk forstand, men også som læreproces.

For det tredje: At lære at bruge et andet sprog og at læse og skrive i et andet skriftsprogligt register end det man er mest fortrolig med, er en kognitiv og samtidig social og identitetsmoessig udfordring. For elever og studerende der bliver undervist på et andetsprog, er det et dagligt vilkår, for andre er det en fremtidig mulighed som er indenfor rækkevidde for flere og flere. I den klasse jeg har fulgt, var begge elevgrupper repræsenteret. Elevtekster og -interviews viser at projektarbejdet havde en realitet og forpligtethed som gjorde at det blev oplevet som en reel udfordring at afprøve fremmedsproget i nye funktioner og på nye måder. Hertil bidrog kompleksiteten, som omtalt ovenfor, men i høj grad også mødet med jævnaldrende der repræsenterer den region og den kulturelle og sproglige problemstilling som eleverne arbejdede med. Derigennem fik projekterne en konkret forankring i en grænseoverskridende virkelighed som gjorde at det blev til mere end en rent akademisk øvelse; sprog og skrift blev brugt til at lære et stykke af verden og dermed sig selv at kende, en ifølge Kern vigtig side af at blive literate. Eller som det siges i elevcitatet ovenfor: Det blev lidt mere virkelighedsrigtigt. 


\section{Litteratur}

Barton, D. (2007) Literacy. An Introduction to the Ecology of Written Language. Malden:Blackwell Beckett, G.H. \& P. C. Miller (eds.) (2006) Project-Based Second and Foreign Language Education. Past, Present, and Future. Greenwich: IAP

Conacher, J.E. \& H. Kelly-Holmes (eds.) (2007) New Learning Environments for Language Learning. Frankfurt a. M.: Peter Lang

Christensen, T. S. (2009) Refleksion og fagsamspil som omdrejningspunkt i skriftlige rapporter. In Vatn, G. Å., I. Folkvord \& J. Smidt (red.) 127-42

Donato, R. (1994) Collective Scaffolding in Second Language Learning. In Lantolf J.P. \& G. Appel (eds.) 33-56

Ehlich, K. (1999) Alltägliche Wissenschaftssprache. Info DaF 1, 3-24

Halliday, M.A.K. (1978) Language as social semiotic. The social interpretation of language and meaning. London: Edward Arnold

Harnow Klausen, S. (red.) (2011) På tvaers af fag. København: Akademisk Forlag

Hermann, M. m. fl. (red.) (2009) Grcenseland - krig og kulturmøde. København:Columbus

Hobel, P. (2009) Almen studieforberedelse og innovativ kompetence. En undersøgelse af 1. G'eres brug af skrivning som medie til innovation i fagligt samspil. Odense: Syddansk Universitet

Hobel, P. (2011) Skrive for at lære og løse problemer. I Harnow Klausen, S. (red.) 139-78

Jakobsen, K. S. (2005) Zweitspracherwerb im Projektstudium. Dänische Erfahrungen aus einem studienvorbereitenden Programm für Zuwanderer. IMIS-Beiträge 26, 63-75

Kern, R. (2000) Literacy and Language Teaching. Oxford University Press

Kramsch, C. (2009) The Multilingual Subject. Oxford University Press

Kress, G. (2003) Literacy in the New Media Age. London:Routledge

Krogh, E. (red.) (2010) Videnskabsretorik og skrivedidaktik. Gymnasiepcedagogik 77

Krogh, E. \& P. Hobel (2012) "Årets bedste opgave": en analyse af en elevtekst i dens kontekst. In Matre, S., D.K. Sjøhelle \& R. Solheim (red.) 137-50

Lantolf, J.P. (ed.) (2000) Sociocultural Theory and Second Language Learning. Oxford UniversityPress

Lantolf, J.P. \& G. Appel (eds.) (1994) Vygotskian Approaches to Second Language Research. Westport: ABLEX Publishing

Maas, U. (2010) Literat und orat. Grundbegriffe der Analyse geschriebener und gesprochener Sprache. Grazer Linguistische Studien 73, 21-150

Matre, S., D.K. Sjøhelle \& Solheim, R. (red.) (2012) Teorier om tekst i møte med skolens lese- og skrivepraksiser. Oslo: Universitetsforlaget

Portmann, P. R. (1991) Schreiben und Lernen. Grundlagen der fremdsprachlichen Schreibdidaktik. Tübingen:Niemeyer

Portmann-Tselikas, P.R. (2002) Textkompetenz und unterrichtlicher Spracherwerb. I PortmannTselikas, Schmölzer-Eibinger (Hrsg.) 13-43

Portmann-Tselikas, P.R. (2005) Was ist Textkompetenz? Universität Graz

Portmann-Tselikas, Schmölzer-Eibinger (Hrsg.) (2002) Textkompetenz. Neue Perspektiven für das Lernen und Lehren. Innsbruck:Studienverlag 
Rampton, B. (2011) Style in a Second Language. Working Papers in Urban Language and Literacies $65 \mathrm{http}: / / \mathrm{www} . k c l . a c . u k /$ innovation/groups/ldc/publications/workingpapers/65.pdf

Schmölzer-Eibinger, S. (2008) Lernen in der Zweitsprache. Grundlagen und Verfahren der Förderung von Textkompetenz. Tübingen: Narr Verlag

Skrivehjulet: En modell for elevers skrivekompetanse http://lesesenteret.uis.no/leseopplaering/ skjulte dokumenter/article2114-975.html. Sidst set

1. 12.2012

Stoller, F. (2006) Establishing a Theoretical Foundation for Project-Based Learning in Second and Foreign Language Contexts. In Beckett. G. H. \& P. C. Miller (eds.) 19-40

Street, B. V. (1995) Social Literacies. Critical Approaches to Literacy in Development, Ethnography and Education. London: Longman

Swain, M (2000) The output hypothesis and beyond: Mediating aquisition through collaborative dialogue. In Lantolf (ed.) 97-114

Togeby, O. (i trykken) Bland bare genrerne

Vatn, G. Å., I. Folkvord \& J. Smidt (red.) (2009) Skriving i kunnskapssamfunnet. Trondheim:Tapir

Vollmer, H. J. (2007) Projects as learning environments in foreign language classrooms in Germany. In Conacher J. E. \& H. Kelly-Holmes (eds.) 45-59

Wood, D., J. S. Bruner, \& G. Ross (1976) The role of tutoring in problem solving. Journal of Child Psychology and Psychiatry 17, 89-100

Zeuner, L. (2012) Fagsamspil og erkendelse i de gymnasiale uddannelser. Frederiksberg: Nyt fra samfundsvidenskaberne 
Appendiks

\begin{abstract}
Wir haben mit dem Grenzland und die Identität gearbeitet. In unsere Aufgabe, haben wir über die dänische Minderheit in Deutschland und der deutschen Minderheit in Dänemark geschrieben. Unsere Fragestellung heißt:

Wie ist es, Teil einer Minderheit und Teil von zwei Kulturen zu sein, und hat es eine Wirkung von der Indentitätbildung? Und welchen Einfluss hat Nationalgefühl für die Mitglieder der Minderheit?

- $\quad$ Es ist Vorteile und Nachteile auf zwei Länder ein Teil sind?

- Welche Einfluss haben die zwei Kulturen auf Indentitätbildung?

- Wie haben die Umzüge auf der deutsche-dänische Grenze im 1920 beeinflussen der Minderheit?

- Warum haben Nationalgefühl Groß Bedeutung von der Persönlichkeit und Identität?
\end{abstract}

Unsere Untersuchung Zeiger welche Vorteile und Nachteile der Minderheit hatte dadurch dass sie ein Teil auf zwei Länder. Heute sieht der Minderheit es mehr oder weniger als einem Vorteil eine Doppeltidentität zu haben, denn sie können zwei Sprachen auf muttersprachlichem Niveau. Unsere Untersuchung Zeigt auch, dass den Grenze, die gegründet wurde im 1920 geht eine Große Bedeutung für die zusammenarbeiten und Frieden durch Dänemark und Deutschland.

\title{
Abstract
}

Vi har arbejdet med grænselandet og identiteten. I vores opgave har vi skrevet om det danske mindretal i Tyskland og det tyske mindretal i Danmark. Vores problemformulering lyder:

Hvordan er det at være del af et mindretal og del af to kulturer, og har det en virkning på identitetsdannelsen? Og hvilken indflydelse har nationalfølelse på medlemmerne af mindretallet?

- Er der fordele og ulemper ved at være en del af to lande?

- Hvilken indflydelse har de to kulturer på identitetsdannelse?

- Hvilken indflydelse har flytningen af den tysk-danske grænse i 1920 haft på mindretallet?

- Hvorfor har nationalfølelse stor betydning for personligheden og identiteten?

Vores undersøgelse viser hvilke fordele og ulemper mindretallet havde ved at være en del af to lande. I dag ser mindretallet det mere eller mindre som en fordel at have en dobbeltidentitet, da de kan to sprog på modersmålsniveau. Vores undersøgelse viser også, at grænsen, som blev grundlagt i 1920, har en stor betydning for samarbejde og fred mellem Danmark og Tyskland. 